\title{
Türkiye İçin Politik İstikrarsızlık Endeksleri: 1955-2009 Dönemi
}

Erdinç TELATAR

erdinc.telatar@okan.edu.tr
Niyazi CANGİR

niyazicangir@maliye.gov.tr

\section{Political Instability Indices for Turkey: The Period of 1955-2009}

\begin{abstract}
The aim of this study is to measure political instability in Turkey for period 1955 through 2009 based on definitions used in new political economics literature. To accomplish the task, in the first place, data regarding social unrest and political violence are obtained through scanning daily Milliyet archive and using the criteria of "Taking part of the first page of the newspaper". Events within the scope of two indicators are scaled again according to "unit event". In the second stage, political instability indices are obtained by applying principal component method to these and the other indicators.
\end{abstract}

Keywords

JEL Classification Codes : A120, Z130.
: Political Instability, Political Instability Index, Principal Component Method, Unit Event.

\section{Özet}

Bu çalışma ile 1955-2009 yıllarını kapsayan dönemde Türkiye'de politik istikrarsızlık olgusunun yeni politik iktisat yazınında kullanılan tanım ve göstergeler esas alınarak ekonometrik çalışmalarda kullanılabilecek bir biçimde ölçülmesi amaçlanmıştır. $\mathrm{Bu}$ çerçevede, istikrarsızlığın sosyal huzursuzluk ve politik şiddet boyutunu yansıtan göstergelere ilişkin veriler Milliyet Gazetesi arşivi taranarak ve "Gazetenin ilk sayfasında yer alma" ölçütü uygulanarak elde edilmiştir. Politik istikrarsızlı̆ı̆ı şiddet boyutunu yansıtan iki değişken kapsamındaki olaylar ayrıca "birim olay"a göre kodlanmıştır. İkinci aşamada ise bu göstergeler ile politik istikrarsızlığı yansıtan diğer göstergelere Temel Bileşenler Yöntemi uygulanarak politik istikrarsızlık endeksleri elde edilmiştir. 
Erdinç TELATAR \& Niyazi CANGİR

\section{Acknowledgement}

This study is regenerated from the dissertation of Niyazi Cangir which was advised by Prof. Erdinc Telatar in 2012.

\section{Beyan}

Bu çalışma Prof.Dr. Erdinç Telatar'ın akademik danışmanlığında Niyazi Cangir tarafindan hazırlanan ve 2012 yılında savunulan doktora tezinden üretilmiştir. 


\section{Giriş}

Politik değişkenlerin makroekonomik göstergeler üzerindeki etkisinin uygulamalı iktisat yazınında ele alınması 1990'lı yıllarda ivme kazanarak önemli bir yoğunluğa ulaşmıştır. $\mathrm{Bu}$ kapsamda, politik sistemin istikrarının makroekonomik değişkenler üzerindeki etkisi ele alınan konuların başında gelmektedir. Politik istikrarsızlığın büyüme, enflasyon, kamu borcu gibi makro değişkenler üzerindeki etkisini irdeleyen teorik modellerin öngörülerinin ampirik olarak test edilebilmesi için öncelikle istikrarsızlık kavramının tanımında ve ölçümünde bir uzlaşmanın sağlanması gerekir. Bu noktada iktisatçlların büyük ölçüde siyaset bilimi ve siyaset sosyolojisinde geliştirilen tanımlar ve sınıflandırmalara bağlı kaldığını söylemek mümkündür. Öte yandan, uygulamalı çalışmalarda kullanılan verilerin de genellikle 1960 ve 1970'li yıllarda anılan disiplinlerin temsilcilerinin koordinasyonunda toplanmaya başlanan veri setlerinden temin edildiği görülmektedir ${ }^{1}$. Bunda, politik istikrarsızlık olgusuna ilişkin alternatif veri kaynaklarının olmayışının belirleyici bir etkisinin olduğu kuşkusuzdur. Veri temini konusunda karşılaşılan kısıtların aynı zamanda yapılan çalışmaların türü üzerinde de etkili olduğu görülmektedir. Konu ile ilgili yazına bakıldığında çalışmaların büyük ölçüde yatay kesit ve panel veriye dayandığı, zaman serisi kullanan çalışmaların yok denecek kadar az olduğu dikkat çekmektedir.

$\mathrm{Bu}$ çalışma ile Türkiye'de politik istikrarsızlı̆̆ın yeni politik iktisat yazındaki tanım ve göstergeler esas alınarak 1955-2009 dönemi için yıllık veriler bazında ölçülmesi amaçlanmaktadır. Dönemin belirlenmesinde politik istikrarsızlık göstergelerine ilişkin sağlıklı verilere erişilebilirlik ve seçilen dönemin zaman serisi çalışmaları için yeterli olması ölçütleri dikkate alınmıştır. Türkiye'de politik istikrarsızlığın ölçülmesi iki aşamalı olarak ele alınmıştır. İlk aşamada politik istikrarsızlık göstergelerine ilişkin veriler elde edilmiştir. Çalışmanın önemli ve özgün yanı, istikrarsızlığın sosyal huzursuzluk ve politik şiddet boyutunu yansıtan göstergelere ilişkin verilerin (olay sayısı) bir tür saha çalışmasıyla elde edilmiş olmasıdır. Konuya ilişkin yazında zaman serisine ve özellikle de yıllık verilere dayanan çalışmalar son derece sınırlıdır ve bu sınırlı sayıdaki çalışmalarda da genellikle "hazır" veriler kullanılmaktadır. İkinci aşamada politik istikrarsızlık göstergeleri kullanılarak politik istikrarsızlık endeksleri oluşturulmuştur. Endekslerin oluşturulmasında Temel Bileşenler Yöntemi (TBY) kullanılmıştır. Türkiye ile ilgili çalışmalarda TBY'nin kullanımı yeni olmamakla birlikte, Demirgil (2011) dışında, politik istikrarsızlık olgusunu yansıtmak için bu yöntemi kullanan çalışmalara araştırmalarımız esnasında rastlanmamıştır. 
Cangir (2012)'ye dayanan bu çalışma üç bölümden oluşmaktadır. İzleyen bölümde politik istikrarsızlık konusunda kısa bir yazın özeti sunulduktan sonra politik istikrarsızlığın göstergeler bazında ölçülmesi konusu ele alınmakta ve bu çerçevede Milliyet Gazetesi arşivinde 1955-2009 dönemini kapsayacak şekilde yapılan çalışma anlatılmaktadır. Çalışmanın IV. Bölümünde tarafımızdan derlenen veriler ile diğer kaynaklardan temin edilen veriler kullanılarak temel bileşenler yöntemi (TBY) ile Türkiye için politik istikrarsızlık endeksleri oluşturulmaktadır. Çalışma elde edilen bulguların kısa bir özeti ile sona ermektedir.

\section{Yazın}

Uygulamalı yeni politik iktisat yazınında politik istikrarsızlığın tanımlanması konusunda esas itibariyle iki yaklaşımın varlığından söz edilebilir. Bu yaklaşımlardan birincisi iktidar değişimi olgusuna, ikincisi ise sosyal huzursuzluk ve politik şiddet olgusuna odaklanmaktadır (Alesina ve Perotti; 1994). Bu ikisi kadar yaygın olmamakla birlikte uygulanan politikalardaki değişkenliğe vurgu yapan yaklaşımlar da vardır. Politik istikrarsızlığın ölçülmesi de bu sınıflandırmaya paralel olarak farklılaşmaktadır.

Politik istikrarsızlı̆̆ın yaygın olarak kullanılan bir tanımı hükümet değişikliği olgusunu esas almaktadır. $\mathrm{Bu}$ yaklaşım aslında siyaset bilimi yazınındaki politik sistemin/rejimin istikrarı düşüncesinden gelmektedir. Burada esas alınan kavram ise süreklilik, yani politik sistemin devamlılığıdır. Martin Lipset'in fikir babası olduğu bu anlayışta politik sistemin istikrarı, değişmeden devam etmesi ile ilişkili olarak anlaşılmaktadır (Lipset, 1959; Lipset, 1964). Buna karşılık, demokrasi ve otokrasi arasında gidip gelmeler politik istikrarsızlı̆ı̆ı bir göstergesi olarak değerlendirilmektedir.

İktisat yazınında politik istikrarsızlığın tanımlanmasında kullanılan bir diğer yaklaşım istikrarı, istikrarsızlaştıııcı olduğu kabul edilen olayların meydana gelme sıklığıyla ilişkili olarak ele almaktadır. Buna göre darbe, askeri müdahale, devrim, suikast, terör olayları, arbede, gösteri, grev gibi şiddet içeren ve içermeyen olayların artması politik istikrarsızlığa işaret etmektedir (Sanders, 1981: 50).

Uygulamalı yazında politik istikrarsızlık esas itibariyle iktidar değişimi olgusu ve/veya sosyal huzursuzluk ve politik şiddet olgusuna odaklanan yaklaşımlar çerçevesinde uygun göstergeler ile yansıtılmaktadır. Politik istikrarsızlığı iktidar değişimi olgusu çerçevesinde ele alan yazında fiili iktidar (hükümet) değişimleri veya probit/logit modelleriyle tahmin edilen "hükümet değişikliği eğilimi" kullanılmaktadır (Alesina ve Perotti, 1994). Politik istikrarsızlığın sosyal huzursuzluk ve politik şiddet olarak alındığı Barro (1991) gibi bazı çalışmalarda tek tek göstergeler kullanılmaktadır. Ancak, bu yönteme genellikle darbe, devrim, savaş, suikast gibi belli başlı olaylar için başvurulmaktadır. Tek tek göstergeler yerine sosyal huzursuzluk olgusunu yansıttığı 
düşünülen bir dizi göstergeden istatistiksel yöntemlerle oluşturulmuş endekslerin kullanılması daha yaygındır. Bu durumda sorun uygun yöntemin seçilmesidir. Basit ortalama (örneğin Mauro, 1995), ayrıştırma (diskriminant) çözümlemesi veya faktör analizi (Örneğin Jong-a-Pin, 2009) yöntemleri de kullanılmakla birlikte yaygın olarak kullanılan yöntem TBY'dir. Böylece, endeks çeşitli göstergelerin bir bileşimi olarak elde edilmekte ve her bir göstergenin katkısı istatistiksel olarak belirlenmiş olmaktadır. Alesina ve Perotti (1996), Perotti (1996), Asteriou ve Price (2001), Fosu (2001) ve Campos ve Nugent (2002) politik istikrarsızlık endeksini TBY'ne göre oluşturan çalışmalardandır (Carmignani, 2003; Drazen, 2002: 522) ${ }^{2}$.

Öte yandan, uygulamalı yazın çok büyük ölçüde az sayıdaki kaynaktan temin edilen panel ve yatay kesit verilere dayanmaktadır. Politik istikrarsızlığ huzursuzluk ve politik şiddet ekseninde ele alan zaman serisi çalışmaları yok denecek kadar azdır. Aynı durumun yine veri sorunundan ötürü Türkiye ile ilgili çalışmalar için de geçerli olduğu söylenebilir. EK: 1'deki Tablodan da görülebileceği üzere, politik istikrarsızlığ 1 hükümet (rejim) değiş̧ikliği ve politika değişkenliği ekseninde ele alan çalışmalar olmakla birlikte sosyal huzursuzluk ve politik şiddet ekseninde ele alan çalışmalara (PKK terörüne odaklanan çalışmalar hariç ${ }^{3}$ ) rastlanmamakta, Şanlısoy ve Kök (2010) ve Demirgil (2011) gibi istisnaî çalışmalar da "hazır" verilere dayanmakta ve/veya kapsanan göstergeler ve dönem sınırlı kalmaktadır. Hem ülkemize ilişkin çalışmalarda hem de konu ile ilgili yazında karşılaşılan bu sorunun temelinde, daha önce belirtildiği üzere, veri sorununun yattı̆̆g düşünülmektedir.

\section{Politik İstikrarsızlığın Ölçülmesi: Politik İstikrarsızlık Göstergeleri}

\subsection{Seçilen Göstergeler}

Türkiye'de 1955-2009 döneminde politik istikrarsızlığı ölçmek için Sanders (1981: 195-199)'in yaptığı tanım ve sınıflandırma esas alınarak şu göstergeler seçilmiştir: Darbe ve askeri müdahaleler, milletvekili genel seçimleri, anayasa değişiklikleri, hükümet değişiklikleri, grevler, gösteriler, şiddet eylemleri, suikastlar ve PKK terörü. Darbe ve askeri müdahaleler ile hükümet değişikliği ve seçimler hükümetteki, anayasa değişiklikleri ise rejimdeki değişiklik olgusunu yakalamayı amaçlamaktadır. Benzeri şekilde, şiddet eylemleri, suikastlar ve PKK terörünün hükümet veya rejime şiddet içeren karşı gelmeyi,

2 Yazında politik istikrarsızlı̆̆ yansıtmak için kullanılan değişkenler konusunda Carmignani (2003), Aron (2000) ve Brunetti (1997)'ye bakalabilir.

3 Tablodaki bu konuya iliş̧kin çalışmalarda örneklem dönemi 1980’li yılların sonlarından itibaren başladı̆̆ için PKK terörünün belirgin bir ağırlığa sahip olması kaçınılmazdır. 
grevler ve gösterilerin ise barışçıl karşı gelmeyi yansıtacağı beklenmektedir. Aşağıda bu göstergeler baz alınarak tanımlanan değişkenlerin ne anlama geldikleri açıklanmaktadır.

Secim değişkeni örneklem döneminde yapılan milletvekili genel seçimlerini göstermektedir.

Hukumet değişkeni örneklem döneminde gerçekleşen yeni bir başbakanın atandığı ve/veya kabinedeki bakanların en az \%50'sinin değiştiği hükümet değişikliklerini göstermektedir.

Anayasa değişkeni örneklem döneminde gerçekleşen iki anayasa değişikliği ile 1961 ve 1982 anayasalarında yapılan ve ele alınan konu açısından önemli değişiklikleri ifade etmektedir. Önemli değişiklik ile rejimin normlarında, parti sistemi türünde ve askeri ve sivil statüde yapılan değişiklikler kastedilmektedir ${ }^{4}$.

Asmud değişkeni 1960, 1971, 1980 ve 1997 yıllarında yapılan darbe ve askeri müdahaleleri ifade etmektedir.

Grev değişkeni örnekleme döneminde kamu ve özel iş yerlerinde gerçekleşen grevlere ilişkin verileri içermektedir.

Gosteri değişkeni işçi, memur ve öğrenciler ile sivil toplum kuruluşları ve diğer toplum kesimlerinin hükümetin izlediği politikalara karşı hoşnutsuzluğunu ve muhalefetini ortaya koyan ve/veya yeni talepler dile getiren ve şiddet (ölüm ve ciddi yaralanma) içermeyen eylemleri ile çeşitli toplum kesimleri arasındaki gerginlik ve kutuplaşmayı yansıtan benzeri eylemleri içermektedir. Belirli dış olaylar karşısında ulusal duruşu simgeleyen eylemler (1950 ve 1960'lı yıllarda Kıbrıs'ta meydana gelen gelişmeleri protesto amacı taşıyan mitingler, 1980'li yıllarda Bulgaristan'da Türk kökenlilere yapılanları protesto mitingleri, 1990'larda Bosna'da Boşnaklara karşı girişilen katliamı protesto mitingleri vb) sosyal huzursuzluğun bir göstergesi olmayıp hükümet karşıtı bir nitelik de taşımadığından kapsam dışında tutulmuştur.

Siddet değişkeni fiziki güç kullanımını içeren, ciddi yaralanma ve/veya ölümlerin gerçekleştiği hükümet ve/veya rejim karşıtı hareketler ile çeşitli gruplar arasında ideolojik ve/veya siyasî nedenlerle gerçekleşen ciddi yaralanma ve/veya ölüm içeren çatışmaları kapsamaktadır. Şehirlerde kitlelere veya belirli hedeflere karşı gerçekleştirilen ve PKK ve diğer terör örgütleri tarafindan üstlenilen şiddet eylemleri bu kapsamda değerlendirilmiştir.

4 Anayasa değişikliklerini politik istikrarsızlı̆̆ın göstergeleri arasında kullanan çalışmalara örnek olarak Aisen ve Veiga (2008) ve Campos ve Karanasos (2008) sayllabilir. 
PKK değişkeni, PKK terör örgütü ile güvenlik güçleri arasında meydana gelen çatışmalar ile terör örgütünün Doğu ve Güneydoğu bölgelerinde esas itibariyle kırsal kesimde diğer kamu görevlileri ve siviller ile yöre halkına karşı giriştiği ciddi yaralanma ve ölüm içeren eylemleri kapsamaktadır.

Suikast değişkeni siyasî ya da ideolojik nedenlerle yüksek düzeydeki politikac1, kamu görevlisi, sivil toplum kuruluşu temsilcisi ve benzeri kişilere karşı girişilen öldürme amacı taşıyan ve çoğunlukla ölümle veya ciddi yaralanma ile sonuçlanan saldırıları ifade etmektedir. Bulunduğu konum itibariyle göreli olarak daha alt düzeyde yer alan politikacı, kamu görevlisi, sivil toplum kuruluşu temsilcisi ve benzeri kişilere karşı girişilen saldırılar ise Siddet göstergesi kapsamında değerlendirilmiştir.

\subsection{Verilerin Elde Edilmesi}

Gosteri, Siddet, Suikast ve PKK değişkenlerine ilişkin veriler (olay sayıları) tarafımızdan derlenmiştir ${ }^{5}$. Bu amaçla 1 Ocak 1955-31 Aralık 2009 dönemi Milliyet Gazetesi arşivi taranmıştır. 1 Ocak 1955-30 Haziran 2004 dönemi için anılan gazetenin internet arşivinden yararlanılırken, 1 Temmuz 2004-31 Aralık 2009 dönemi için Gazetenin Milli Kütüphanedeki arşivi kullanılmıştır. Milliyet Gazetesinin seçilmesinin temel nedeni 3 Mayıs 1950 tarihinden 30 Haziran 2004 tarihine kadar olan dönemi kapsayan internet arşivinin erişime açık olmasıdır. Tüm örneklem dönemi için aynı kaynağın kullanılması, farklı kaynakların kullanılmasından kaynaklanabilecek ölçüm sapmalarının en az düzeyde tutulması açısından önemlidir.

Yukarıda belirtilen dört gösterge için birincil kaynak Milliyet Gazetesi olmakla birlikte diğer kaynaklardan da yararlanılmıştır. Anadolu Ajansı (AA) (2010) 1919 yılından 2009 yılının sonuna kadar meydana gelen önemli olayları kronolojik olarak vermektedir. Çok önemli bir kaynak olmakla birlikte, kronolojide yer alan olayların seçiminde son yıllar lehine çok belirgin bir sapma görülmektedir. Bu nedenle de olayların seçiminde tüm yıllar için aynı ölçütün uygulanmamış olması sorunu ortaya çıkmakta, bu ise ölçümü esastan etkilemektedir. Bu nedenle anılan kaynak esas itibariyle Milliyet Gazetesinden elde edilen bulguları desteklemek ve doğrulamak için kullanılmıştır. Gosteri değişkenine ilişkin verilerin oluşturulmasında ayrıca Türk-İş ve DİSK'in internet sitelerinde yayımladıkları eylemlerden (DİSK için etkinlikler dizininden) de yararlanılmıştır. Bunların dışında diğer bazı ikincil olarak nitelendirilebilecek kaynaklar yukarıda belirtilen kaynaklardan elde edilen bulguları kontrol etmek amacıyla incelenmiştir. Çoğunlukla örneklem döneminin belirli alt dönemlerini kapsayan bu kaynaklara örnek olarak Siddet değişkeni için Ahmad ve Ahmad (1976), Keleş ve Ünsal (1982) ve Başbakanlık (1983) sayılabilir. PKK

\footnotetext{
5 Diğer değişkenlere iliş̧kin veriler ve kaynaklarl için Bkz. Cangir (2012: EK: 2).
} 
değişkeni için ise Wikipedia internet sitesinde yayımlanan PKK saldırı ve çatışmalarına ilişkin kronolojik olaylar ${ }^{6}$ örnek olarak gösterilebilir.

Gosteri, Siddet, Suikast ve PKK değişkenlerine ilişkin veriler "olay sayısı”" bazında derlenmiştir. Olay sayısının belirlenmesinde ise kural olarak "Milliyet Gazetesinin ilk sayfasında yer alma" ölçütü uygulanmıştır. Bununla birlikte, özellikle Gosteri değişkeni kapsamındaki olayların belirlenmesi sırasında zaman zaman bu ölçütün gevşetilmesi ihtiyacı ortaya çıkmıştır. Örneğin, Türk-İş ve DİSK'in kendi kayıtlarında yer alan gösteri ve mitinglerin bir kısmına Gazetenin ilk sayfasında yer verilmemiştir. Bunda o gün itibariyle anılan eylemlerin diğer olayların gölgesinde kalması da etkili olmuştur. Bu ve benzeri durumlarda, anılan eylemlere ilişkin, katılan toplumsal kesimlerin sayısı, katılan kişi sayısı, eylemin yapıldığı il sayısı gibi ek bilgilerden yararlanılarak olayın kapsama alınıp alınmamasına karar verilmiştir.

Olay sayısının belirlenmesinde "Milliyet Gazetesinin birinci sayfasında yer alma" ölçütünün uygulanması belirli ölçek ve önemdeki olayların kodlanmasını sağlayarak önemli bir referans noktası (benchmark) işlevi görmüştür. Siddet ve PKK değişkenlerine ilişkin olay sayısının belirlenmesinde anılan ölçüt daha da inceltilerek "birim olay" tanımlanmıştır. Böylece, Gazetenin ilk sayfasında yer alan olaylar da sayfada yer aldıkları göreli öneme göre kendi arasında ölçeklendirmeye tabi tutulmuştur ${ }^{7}$. Yazında ölçeklendirme yapan veya bu tür verileri kullanan çalışmalara sık rastlanmakta olup örnek olarak Berthelemy vd. (2002), Busse ve Hefeker (2007), Dutt ve Mitra (2008) ve Telatar vd. (2009) sayllabilir.

Siddet ve PKK değişkenleri kapsamında yer alan bir olayın "birim olay" olarak değerlendirilmesinde olayın Gazetenin ilk sayfasındaki göreli önemi ve bazı durumlarda ayrıca ölen kişi sayısı ölçütleri kullanılmıştır ${ }^{8}$. Gazetenin birinci sayfasında manşet veya buna yakın büyüklükte yer alan olaylar bir birim olarak kodlanırken birinci sayfada yer alan diğer olaylarda gruplandırmaya gidilmiştir. Bununla iki, üç, dört ve istisnai bazı durumlarda beş tane olayın bir birim olay olarak kaydedilmesi kastedilmektedir. Öte yandan, 1 Mayıs 1977 'de Taksim'de meydana gelen olaylar, Aralık 1978'de meydana gelen K.Maraş olayları, Temmuz 1993'te Sivas'ta meydana gelen olaylar ve Mart

6 Bkz. <http:://tr.wikipedia.org/wiki/pkk saldırllarl>. Daha önce de erişilen sitedeki bilgiler 16 Haziran 2011 tarihli erişimde "PKK saldırlları ve çatışmaları kronolojisi” başlı̆̆ altında "1978-1989”, "1990-1999”, “2000-2009”, “2010-günümüz” şeklinde dört ayrl dosya halinde verilmektedir.

7 Suikast göstergesi tanımı gereği esas itibariyle böyle bir ölçeklendirme içerdiğinden, Gosteri kapsamındaki olaylar ise genellikle şiddet ve terör olaylarının gölgesinde kaldı̆̆l ve bu nedenle de Gazetedeki göreli önem ölçütünü işlevsiz hale getirdiği için "birim olay” kapsamı dışında tutulmuştur.

8 Bir olayın "haber değeri” ile toplumsal etkisinin büyüklüğünün farklılaştığı bazı dönem ve olaylarda ayrıca "ölen kişi sayısı” ölçütü de değerlendirmeye alınarak ölçüm sapması en aza indirilmeye çalışılmıştır. Daha çok 1978-1980 dönemi için başvurulan bu uygulamaya neden ihtiyaç duyulduğuna ilişkin açıklama için Cangir (2012: 128-129)'e bakllabilir. 
1995 'teki Gazi Mahallesi olayları gibi büyük ölçekli olaylar ile Kuzey Irak'a yapılan bazı harekâtlar için küçük çaplı olaylarda yapılan ölçeklendirmeye paralel olarak bir olay beş birim olaya kadar giden bir ölçekte değerlendirilmiştir. Bu ölçeklendirme yapılırken de yine "göreli önem" ve "ölen kişi sayısı" ölçütleri esas alınmıştır. Böylece bu iki değiş̧ken kapsamında yer alan olaylar 25 birimlik bir ölçeğe göre ölçeklendirilmiştir?.

Siddet değişkeninin grafiği aşağıda yer almaktadır. Gosteri, PKK ve Suikast değişkenlerine ilişkin grafikler ise EK: 2'de sunulmaktadır.

Grafik: 1 - Siddet Değişkeni (1955-2009).

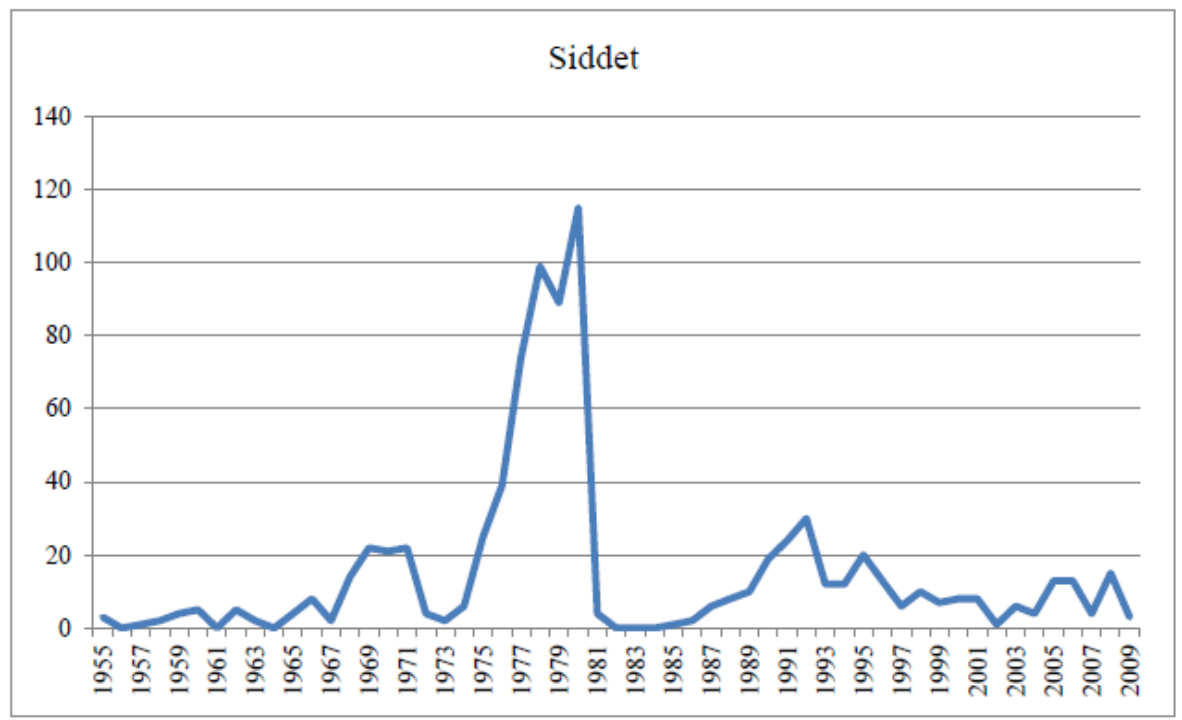

Grafikten de görüldüğü üzere şiddet olayları 1978-1980 döneminde yoğunlaşmakta, 1969-1970 ve 1991 yıllarında da bir artış göze çarpmaktadır.

\section{Politik İstikrarsızlığın Ölçülmesi: Politik İstikrarsızlık Endeksleri}

Türkiye'de politik istikrarsızlık olgusunu yansıtmak için bir önceki bölümde sayılan 9 değişkene (Siddet, Suikast, Gosteri, PKK, Asmud, Anayasa, Grev, Secim,

9 Siddet ve PKK değişkenlerinde uygulanan ölçeklendirme konusunda daha ayrıntılı bilgi için Cangir (2012: 127-130)'e bakalabilir. 
Hukumet) TBY uygulanarak politik istikrarsızlık endeksleri oluşturulmuştur. Politik istikrarsızlık endeksleri, 1955-2009 dönemine ilişkin yıllık veriler kullanılarak elde edilmiştir.

Tablo: 1

İstikrarsızlık Göstergelerine İlişkin İstatistikler

\begin{tabular}{lccccccccc}
\hline & Ana & Asmud & Gos & Grev & Huk & PKK & Sid & Suik & Secim \\
\hline Ortalama & 0,3 & 0,1 & 8,6 & 67,4 & 0,8 & 7,0 & 15,0 & 1,2 & 0,2 \\
Ortanca & 0,0 & 0,0 & 6,0 & 38 & 1,0 & 0,0 & 6,0 & 0,0 & 0,0 \\
Max & 1,0 & 1,0 & 27,0 & 458 & 2,0 & 39,0 & 114 & 11 & 1,0 \\
Min. & 0,0 & 0,0 & 0,0 & 0,0 & 0,0 & 0,0 & 0,0 & 0,0 & 0,0 \\
S.Sapma & $\mathbf{0 , 5}$ & $\mathbf{0 , 3}$ & $\mathbf{7 , 3}$ & $\mathbf{9 2 , 3}$ & $\mathbf{0 , 8}$ & $\mathbf{1 0 , 6}$ & $\mathbf{2 4 , 2}$ & $\mathbf{2 , 2}$ & $\mathbf{0 , 4}$ \\
Çarpıklık & 0,8 & 3,3 & 0,7 & 2,6 & 0,4 & 1,4 & 2,8 & 2,5 & 1,2 \\
Basıklık & 1,7 & 11,8 & 2,5 & 10,3 & 1,7 & 4,0 & 10,4 & 9,9 & 2,5 \\
J.Bera & 10,2 & 278 & 5,3 & 184 & 5,4 & 21 & 198 & 168 & 14,6 \\
Toplam & 17,0 & 4,0 & 471 & 3705 & 42 & 385 & 825 & 66 & 13 \\
Gözlem & 55 & 55 & 55 & 55 & 55 & 55 & 55 & 55 & 55 \\
\hline
\end{tabular}

Endekslerin elde edilmesinde kullanılan ham verilere ilişkin istatistikler Tablo: 1 'de yer almaktadır. Bu tabloda ele alınan konu açısından en önemli özellik değişkenlerin standart sapmaları arasındaki belirgin farklılıktır. Temel bileşenler analizinin anlamlı olabilmesi için değişkenlerin aynı, en azından karşılaştırılabilir, ölçü birimiyle ölçülmesi ve varyanslarının kabaca aynı büyüklükte olması gerekir. Değişkenlerin varyansları arasında büyük farklılıkların olduğu durumda kovaryans matrisi esas alındığında varyansı büyük olan değişkenler sırasıyla temel bileşenleri domine etmektedir ki bu durumda analiz yapmanın bir anlamı kalmamaktadır (Johnson, 1998: 108). Değişkenlerin ölçü birimlerinin farklı olmasından ileri gelen bu gibi durumlarda değişkenlerin birim varyansa sahip olacak şekilde standartlaştırılması, eş deyişle, TBY'de korelasyon matrisinin esas alınması gerekir. Tablo: 3'deki temel bileşenlere iliş̧in katsayılardan, değişkenlerin varyanslarının büyüklüğüne göre sırasılyla her bir temel bileşeni belirlediği görülmektedir. Örneğin, varyansı en büyük olan Grev değişkeni neredeyse tek başına 1 nolu temel bileşeni belirlemekte, 1 nolu bileşen ise verilerdeki değişimin \%93'ünü açıklamaktadır (Tablo: 2). Benzeri şekilde, Siddet değişkeni 2 nolu temel bileşeni, PKK değişkeni 3 nolu bileşeni belirlemekte, diğer temel bileşenlerde de aynı örüntü devam etmektedir. 
Tablo: 2

Kovaryans Matrisine Göre Hesaplanan Özdeğerler

\begin{tabular}{cccc}
\hline Sayı & Değer & Oran & Birikimli Oran \\
\hline TB1 & 8440 & 0,93 & 0,93 \\
TB2 & 517 & 0,06 & 0,98 \\
TB3 & 118 & 0,01 & 1,00 \\
TB4 & 34,3 & 0,00 & 1,00 \\
TB5 & 2,28 & 0,00 & 1,00 \\
TB6 & 0,66 & 0,00 & 1,00 \\
TB7 & 0,21 & 0,00 & 1,00 \\
TB8 & 0,11 & 0,00 & 1,00 \\
TB9 & 0,06 & 0,00 & 1,00 \\
\hline Özdeğerler: (Toplam $=$ 9112, Ortalama $=1012)$ &
\end{tabular}

İlk iki bileşenin açıkladığı varyansın oranı ise \%98'i bulmaktadır. Buna göre, kovaryans matrisinden hareketle elde edilen temel bileşenlerin istikrarsızlık endeksi olarak alınması uygun olmayacaktır. Çünkü bu durumun varyansı yüksek değişkenlerin sırasıyla istikrarsızlık endeksi olarak alınmasından farkı yoktur. Kovaryans matrisine göre yapılan hesaplamadan elde edilen sonuçlar verilerin standartlaştırılması gereğini açıkça ortaya koymaktadır. Bir başka deyişle, hesaplamanın korelasyon matrisi esas alınarak yapılması gerekir. $\mathrm{Bu}$ durumda verilerin standart sapmaları bire eşit olduğundan ham verilerde varyansı büyük olan değişkenlerin orantısız bir biçimde analizi etkilemesi sakıncası giderilmiş olmaktadır.

Tablo: 3

Kovaryans Matrisine Göre Hesaplanan Özvektörler

\begin{tabular}{lccccccccc}
\hline Değişken & TB 1 & TB 2 & TB 3 & TB 4 & TB 5 & TB 6 & TB 7 & TB 8 & TB 9 \\
\hline ANA & 0,00 & 0,00 & 0,01 & $-0,01$ & 0,00 & 0,21 & $\mathbf{0 , 8 3}$ & 0,50 & $-0,07$ \\
ASMUD & 0,00 & 0,00 & 0,00 & 0,00 & $-0,04$ & 0,06 & $-0,14$ & 0,33 & $\mathbf{0 , 9 3}$ \\
GOS & 0,01 & $-0,02$ & 0,45 & $\mathbf{0 , 8 9}$ & 0,06 & 0,00 & 0,01 & 0,00 & 0,00 \\
GREV & $\mathbf{1 , 0 0}$ & $-0,09$ & $-0,04$ & 0,01 & 0,00 & 0,00 & 0,00 & 0,00 & 0,00 \\
HUK & 0,00 & 0,00 & 0,00 & 0,00 & $-0,04$ & $\mathbf{0 , 9 3}$ & $-0,32$ & 0,12 & $-0,15$ \\
SECIM & 0,00 & 0,00 & 0,00 & $-0,01$ & $-0,02$ & 0,30 & 0,43 & $-0,79$ & 0,33 \\
SID & 0,09 & $\mathbf{0 , 9 9}$ & 0,09 & $-0,02$ & $-0,05$ & 0,00 & 0,00 & 0,00 & 0,00 \\
SUIK & 0,01 & 0,05 & 0,04 & $-0,09$ & $\mathbf{0 , 9 9}$ & 0,04 & $-0,01$ & 0,01 & 0,04 \\
PKK & 0,03 & $-0,09$ & $\mathbf{0 , 8 9}$ & $-0,45$ & $-0,07$ & 0,00 & $-0,01$ & 0,00 & 0,00 \\
\hline
\end{tabular}

Tablo: 4 temel bileşenler analizinde kullanılan değişkenler arasındaki korelasyonları göstermektedir. Temel bileşenler analizinin anlamlı olabilmesi için değişkenler arasında korelasyon olması gerekir. Değişkenler arasındaki korelasyon sıfır ise temel bileşenler analizi yapılmasının bir anlamı yoktur ${ }^{10}$. Tablo: 4 çok yüksek olmasa da 10 Ĕger değişkenlerin hiçbiri arasında korelasyon yoksa değişkenlerin kendisi temel bileşen olacaktır.
Korelasyonlar küçük ise temel bileşenler büyük ölçüde değişkenleri dublike edecektir (Rencher, 2002: 402). 
bazı değişkenler arasında korelasyon olduğunu göstermektedir. Temel bileşenler analizi yapılmasının anlamlı olup olmadığını belirlemek için korelasyon veya kovaryans matrisinin diyagonal olup olmadığ test edilmektedir. Örneklem korelasyon matrisi R için boş hipotez $H_{0}: R=I$ şeklinde ifade edilebilir. Bu hipotez örneklem korelasyon matrisindeki bireysel değişkenlerin ilişkisiz (korelasyonsuz) olup olmadığını sınamaktadır. Hipotezin doğru olması korelasyon matrisinin birim (identity) matrisi olması anlamına gelmektedir. Bu hipotezi sınamak için test istatistiği $V=|R|$ ile verilmektedir. N'nin büyük değerleri için $-a \log V \phi \chi_{\alpha, p(p-1) / 2}^{2}$ ise $H_{0}$ red edilir. Eğer $H_{0}$ red edilemez ise temel bileşenler analizi yapılmamalıdır. Yukarıdaki istatistikte, $\mathrm{N}$ örneklem hacmini, $p$ değişken sayısını ve $a=N-1-(2 p+5) / 6$ göstermektedir (Johnson,1998: 111; Rencher, 2002: 265).

\section{Tablo: 4}

\section{Değişkenler Arasındaki Korelasyonlar}

\begin{tabular}{lccccccccc}
\hline & ANA & ASMUD & GOS & GREV & HUK & SECIM & SID & SUIK & PKK \\
\hline ANA & 1,00 & & & & & & & & \\
ASMUD & $-0,04$ & 1,00 & & & & & & & \\
GOS & 0,05 & 0,04 & 1,00 & & & & & & \\
GREV & $-0,04$ & 0,05 & 0,12 & 1,00 & & & & & \\
HUK & 0,20 & 0,26 & 0,03 & 0,15 & 1,00 & & & & \\
SECIM & 0,37 & $-0,16$ & $-0,07$ & 0,14 & 0,44 & 1,00 & & & \\
SID & $-0,15$ & 0,25 & 0,00 & 0,32 & 0,14 & $-0,06$ & 1,00 & & \\
SUIK & $-0,06$ & $-0,03$ & $-0,02$ & 0,41 & 0,07 & $-0,03$ & 0,63 & 1,00 & \\
PKK & 0,15 & $-0,03$ & 0,48 & 0,25 & 0,01 & 0,02 & $-0,06$ & 0,22 & 1,00 \\
\hline
\end{tabular}

Yapılan hesaplamalar $H_{0}$ hipotezinin red edildiğini göstermektedir ${ }^{11}$. Buna göre, TBY uygulanarak 9 tane politik istikrarsızlık göstergesini temsil edecek daha az sayıda anlamlı bileşik değişken elde edilmesi mümkündür.

Standartlaştırılmış verilere göre (korelasyon matrisine göre) analiz yapıldığında temel bileşenlere ilişkin karakteristik köklerin aldığı değerler Tablo: 5'de gösterilmektedir. Veriler standartlaştırıldığı için karakteristik köklerin ortalama değeri bir, toplam değeri ise

11 Bu hipotez için test istatistiği örneklem korelasyon matrisinin determinantının hesaplanmasın gerektirmektedir. Bir matrisin karakteristik köklerinin (öz değerlerinin) çarpımı determinantını verdiğinden Tablo: 4'deki örneklem korelasyon matrisinin determinant, Tablo: 5'de verilen özdeğerlerin çarpllmasıyla, 0,136 olarak hesaplanmaktadir. Bu durumda test istatistiği $-a \log V=-490,2 \times \log (0,136)=-490.2 \times-0,868=425,4$ olarak bulunmaktadır. Anılan hipoteze ilişkin istatistiğin tablo değeri $\chi^{2} \alpha, p(p-1) / 2 \alpha=0.01$ için $\left(\chi^{2}{ }_{0.01 ; 36}\right)$ yaklaşık olarak 58 olduğundan $H_{0}$ hipotezi red edilecektir. 
temel bileşen sayısı kadardır. Tablonun "değer" sütununda her bir karakteristik kökün aldığı değer, oran sütununda ise, toplam varyansın ne kadarını açıkladığı gösterilmektedir. Tabloya göre, ilk dört temel bileşene ilişkin karakteristik kök ortalama değerden daha yükssek bir değer almıştır. Bu dört temel bileşenin açıkladığı varyans oranının toplamı ise $\% 72$ 'dir.

Tablo: 5

Korelasyon Matrisine Göre Hesaplanan Özdeğerler

\begin{tabular}{cccc}
\hline Sayı & Değer & Oran & B.Oran \\
\hline TB1 & 2,088 & 0,23 & 0,23 \\
TB2 & 1,724 & 0,19 & 0,42 \\
TB3 & 1,511 & 0,17 & 0,59 \\
TB4 & 1,168 & 0,13 & 0,72 \\
TB5 & 0,761 & 0,08 & 0,81 \\
TB6 & 0,622 & 0,07 & 0,87 \\
TB7 & 0,507 & 0,06 & 0,93 \\
TB8 & 0,393 & 0,04 & 0,97 \\
TB9 & 0,226 & 0,03 & 1,00 \\
\hline
\end{tabular}

Toplam

Temel bileşenler analizi formal olarak başlangıçtaki değişken sayısı kadar temel bileşen üretmektedir. Bununla birlikte, analizden beklenen sonuç az sayıdaki temel bileşen verilerdeki değişimin önemli bir kısmını açıkladığı takdirde elde edilmektedir. Literatürde konu ile ilgili olarak önerilen açıklanan varyans, Kaiser ve yığın grafiği gibi ölçütler (OECD, 2008: 70; Rencher, 2002: 397; Johnson, 1998: 99) dikkate alındığında dört tane bileşenin seçilebileceği ortaya çıkmaktadır.

Korelasyon matrisine göre hesaplanan karakteristik köklerden seçilen ilk dört tanesine ilişkin katsayılar (öz vektörler) Tablo: 6' da yer almaktadır ${ }^{12}$. Tablonun incelenmesinden şu özellikler dikkat çekmektedir. Orijinal veriler arasındaki korelasyon pozitif ise birinci temel bileşenin katsayıları (birinci öz vektör) pozitif olmakta, bu nedenle de 1 nolu temel bileşen genellikle analize dahil edilen değişkenlerin ağırlıklı bir ortalaması olmaktadır. $\mathrm{Bu}$ durumda diğer öz vektörler birincisine ortogonal olduğu için bu öz vektörlerde hem pozitif hem de negatif katsayıların olması zorunludur (Bartholomew vd, 2002: 123; Rencher, 2002: 403). Tablo 6'daki temel bileşen katsayıları bu özelliği yansıtmaktadır. Tablo: 4'de negatif korelasyonlar da olmakla birlikte bunların değeri biri

12 Bu özvektörler (variable loadings) ve buna dayanılarak elde edilen temel bileşen serilerinin (observation scores) hesaplanmasında normal korelasyon (ordinary correlation) baz alınmıstır. Ewievs 7.0 programının sunduğu diğer alternatiflere (Spearman's rank order, Kendall's tau-a ve Kendall's tau-b) göre de hesaplama yapılmıştır. Son iki kritere göre elde edilen temel bileşenler ile analizlerde esas alınan temel bileşenler arasındaki korelasyon \%100 civarında iken Spearman's rank-order korelasyonuna göre hesaplanan temel bileşenler bir miktar farklılık göstermektedir. 
dışında \% 10 'nun altındadır ve 0.20 'den büyük korelasyon katsayılarının tamamının işareti pozitiftir. TB1'de sadece Anayasa değişkeninin katsayısı negatiftir, ancak ihmal edilebilecek bir büyüklüğe sahiptir. Diğer temel bileşenlerde hem pozitif hem de negatif katsayılar vardır.

Tablo: 6

Korelasyon Matrisine Göre Hesaplanan Katsayılar (Özvektörler)

\begin{tabular}{lcccc}
\hline Değişken & TB1 & TB2 & TB3 & TB4 \\
\hline ANAYASA & $-0,006$ & 0,544 & $-0,018$ & $-0,048$ \\
ASMUD & 0,176 & $-0,090$ & $-0,204$ & 0,781 \\
GOSTERI & 0,166 & 0,150 & 0,588 & 0,318 \\
GREV & 0,490 & 0,042 & 0,065 & $-0,170$ \\
HUKUMET & 0,252 & 0,418 & $-0,353$ & 0,309 \\
SIDDET & 0,516 & $-0,275$ & $-0,234$ & 0,005 \\
SECIM & 0,087 & 0,581 & $-0,268$ & $-0,237$ \\
PKK & 0,264 & 0,223 & 0,597 & 0,031 \\
SUIKAST & 0,543 & $-0,184$ & $-0,034$ & $-0,323$ \\
\hline
\end{tabular}

İlk dört temel bileşene ilişkin Tablo: 6'daki katsayılar (vektörler) standartlaştırılmış verilere uygulanarak TB1, TB2, TB3 ve TB4 olarak kodlanan dört tane seri elde edilmiştir (Grafik: 2 ve EK: 3). Bu serilerin her birinin politik istikrarsızlık olgusunun farklı boyutlarını yansıtan endeksler olarak değerlendirilmesi mümkündür. TB1, Anayasa değişkeni hariç, analize dâhil edilen diğer sekiz değişkenin ağırlıklarının pozitif olduğu ağırlıklı bir ortalaması gibidir. Suikast, Siddet ve Grev değişkenlerinin göreli ağırlıkları daha büyük olmakla birlikte, TB1'in ele alınan politik istikrarsızlık olgusunun en iyi ölçütü olduğu söylenebilir. TB2'de Anayasa, Seçim ve Hukumet değişkenlerinin katsayıları göreli olarak daha büyük iken TB3'de PKK ve Gosteri değişkenlerinin katsayıları, TB4'de ise AsMud değişkeninin katsayısı ön plana çıkmaktadır.

TB1 politik istikrarsızlığın göstergesi olarak alındığında, Garfik: 2'den de görülebileceği üzere, politik istikrarsızlık 1978, 1979, 1980, 1990 ve 1991 yıllarında doruk noktasına çıkmaktadır. Bu yükselişte 1978-1980 döneminde Siddet, Suikast ve Grev değiş̧kenlerinin, 1990 ve 1991 yıllarında ise bunlara ek olarak PKK değişkeninin belirleyici bir etkisinin olduğu söylenebilir. 
Grafik: 2 - Politik İstikrarsızlık Endeksi (1955-2009).

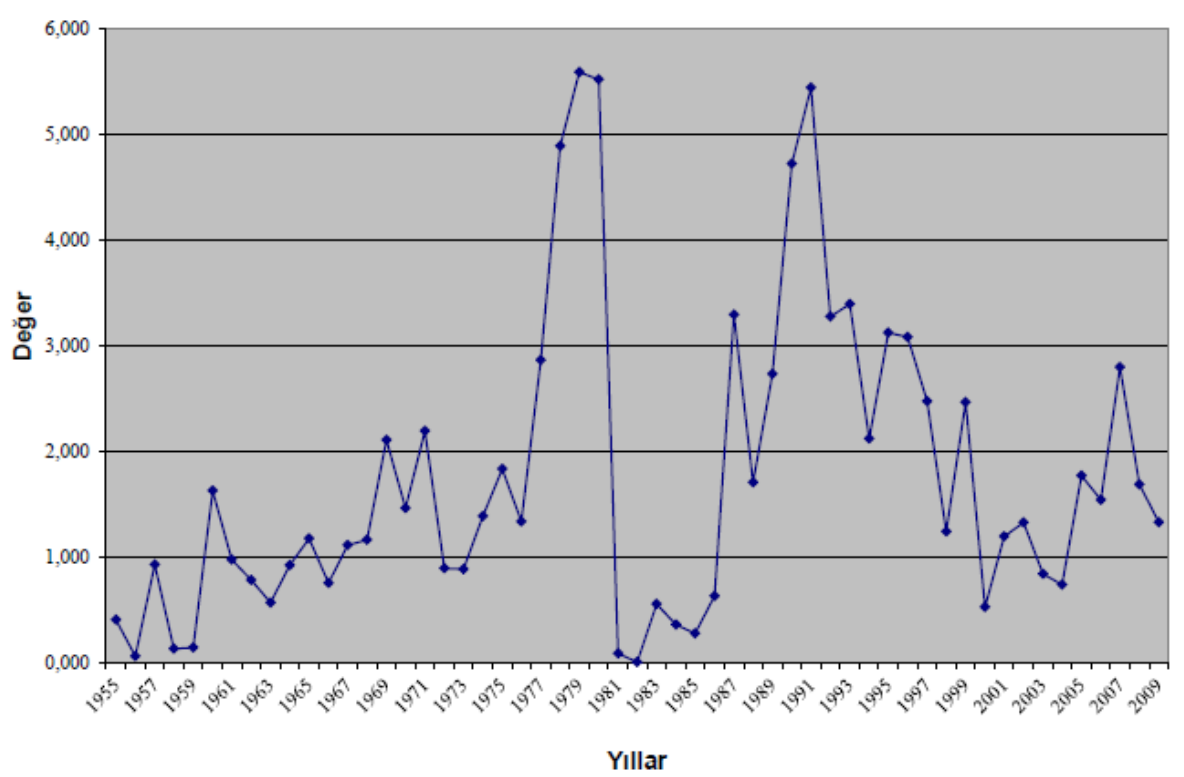

\section{Sonuç}

Kapsamlı bir gazete arşivi taramasına dayanan bu çalışma ile Türkiye için 19552009 dönemini kapsayacak şekilde politik istikrarsızlığın uygulamalı yeni politik iktisat yazınında kullanılan tanım ve göstergeler esas alınarak ekonometrik çalışmalarda kullanılabilecek bir biçimde ölçülmesi amaçlanmıştır. Bu çerçevede önce politik istikrarsızlığın sosyal huzursuzluk boyutunu yansıtan göstergelere ilişkin veriler (olay sayıları) Milliyet Gazetesi arşivi ve diğer kaynaklardan yararlanılarak elde edilmiştir. Anılan göstergelere ilişkin ölçüm yapılırken bütün örneklem dönemi boyunca aynı ölçütün uygulanması gereğine özellikle dikkat edilmiş, seçilen ölçütlerin politik istikrarsızlık olgusunu yansıtmada sapma gösterdiğinin fark edildiği dönem ve olaylarda gerekli uyarlamalar yapılmıştır. Çatışma sayısı, çatışmalarda yaralanan ve ölen kişi sayısı gibi yazında sıkça kullanılan ölçütler yerine "olay sayısı"nın seçilmesi, araştırma konusu olguyu ölçüm sapmalarını en aza indirecek şekilde sayısallaştırma çabasının bir sonucudur. Öte yandan, bir olayın "haber değeri" ile toplumsal etkisinin büyüklüğünün farklılaştığ bazı dönem ve olaylarda ayrıca "ölen kişi sayısı" ölçütü de değerlendirmeye alınarak ölçüm sapması en aza indirilmeye çalışılmıştır. Buna karşılık, sonuçların 
değerlendirilmesi sırasında politik istikrarsızlık gibi olguların sayısallaştırılmasında iki temel güçlüğün bulunduğunun gözden uzak tutulmaması gerekir. Birincisi, seçilen göstergelerin ölçülmeye çalışılan olguyu tam olarak yansıtma sorunu vardır. Bu noktada iktisatçıların ilgili disiplinlerin geliştirdiği tanım ve göstergelere bağlı kalması sorunu ortadan kaldırmamaktadır. İkincisi, terör, şiddet, gösteri, suikast vb gibi göstergeler kapsamındaki olayların standartlaştııılması ve karşılaştııılabilir hale getirilmesi son derece güçtür ve kaçınılmaz olarak sübjektiflikler içermektedir. Öte yandan, zaman serisi verilerinde örneklem döneminin uzaması bu sorunu daha da karmaşı hale getirmektedir. $\mathrm{Bu}$ güçlüklere karşılık, olay sayısının gazetenin ilk sayfasında yer alma ölçütüne göre belirlenmesi ve ayrıca Siddet ve PKK değişkenlerine iliş̧in verilerin oluşturulmasında kullanılan "birim olay" kanımızca çalışmanın önemli ve özgün bir özelliğini oluşturmaktadır. Çalışmanın ikinci aşamasında politik istikrarsızlık göstergelerine TBY uygulanarak politik istikrarsızlık endeksleri elde edilmiştir. Uygulanan yöntemin kurgusu gereği politik istikrarsızlık olgusunu en iyi yansıtması beklenen 1 nolu endeksin Türkiye'deki politik istikrarsızlık olgusunu yansıtmakta başarılı olduğu değerlendirilmektedir. Öte yandan, tarafımızdan gazete arşivinden derlenen politik istikrarsızlık göstergeleri ve oluşturulan politik istikrarsızlık endeksleri makroekonomik performansı yansıtan değişkenlere (büyüme, enflasyon ve cari denge) ilişkin regresyon tahminlerinde kullanılmış ve beklentiler yönünde anlamlı sonuçlar elde edilmiştir (Cangir, 2012: 147-164).

\section{Kaynakça}

Ahmad, F. \& B.T. Ahmad (1976), Türkiye'de Çok Partili Politikanın Açılkamalı Kronolojisi 19451971, Ankara: Bilgi Yayınevi.

Aisen, A. \& F.J. Veiga (2008), “The Political Economy of Seigniorage”, Journal of Development Economics, Vol. 87(1), 29-50.

Alesina, A. \& R. Perotti (1994), "The political Economy of Growth: A Critical Survey of Recent Literature", The World Bank Economic Review, Vol. 8 (3).

Alesina, A. \& R. Perotti (1996), "Income Distribution, Political Instability and Investment", European Economic Review, 40, 1203-1228.

Anadolu Ajans1 (2010), Türkiye'nin 90 Yll, Ankara: Anadolu Ajansı Genel Müdürlüğü.

Araz-Takay, B. \& K.P. Arın \& T. Omay (2009), "The Endogenous and Non-Linear Relationship between Terrorism and Economic Performance: Turkish Evidence", Defence and Peace Economics, Vol. 20(1), 1-10.

Aron, J. (2000), "Growth and Institutions", The World Bank Research Observer, Vol. 15(1), 99-135. Arslan, Ü. (2011), "Siyasî İstikrarsızlık ve Ekonomik Performans: Türkiye Örneği”, Ege Akademik Bakıs, Cilt 11(1), 73-80. 
Asteriou, D. \& S. Price (2001), "Political instability and Economic Growth: UK Time Series

Evidence", Scottish Journal of Political Economy, Vol. 48(4), 383-399.

Barro, R.J. (1991), "Economic Growth in a Cross Section of Countries", The Quarterly Journal of Economics, Vol. 106(2), 407-443.

Bartholomew, D.J. \& F. Steele \& I. Moustaki \& J.I. Galbraith (2002), The Analysis and Interpretation of Multivariate Data for Social Scientists, Chapman\&Hall.

Başbakanlık (1983), Terör ve Terörle Mücadelede Durum Değerlendirmesi, Ankara, Başbakanlık Basımevi.

Başbakanlık (1998), Türkiye Büyük Millet Meclisinin Kuruluşundan Günümüze Hükümetler, Ankara: Başbakanlık Personel ve Prensipler Genel Müdürlüğü.

Berthelemy, J-C. \& C. Kauffmann \& L. Renard \& L. Wegner (2002), Political Instability, Political Regimes and Economic Performance in African Countries, $<$ www.csae.ox.ac.uk/conferences/2002-upagissa/papers/kauffmann-csae2002.pdf>, 23.9.2008.

Brunetti, A. (1997), "Political Variables in Cross-Country Growth Analysis", Journal of Political Economic Surveys, Vol. 11(2), 163-190.

Busse, M. \& C. Hefeker (2007), "Political Risk, Institutions and Foreign Direct Investment", European Journal of Political Economy, 23, 397-415.

Campos, N.F. \& J.B. Nugent (2002), "Who is Afraid of Political Instability?”, Journal of Development Economics, Vol. 67, 157-172.

Campos, N.F. \& M.G. Karanasos (2008), "Growth, Volatility and Political Instability: Non-linear Time-series Evidence For Argentina, 1896-2000”, Economics Letters, 100, 135-137.

Cangir, N. (2012), "Politik İstikrarsızlık ve Makroekonomik Performans İlişkisi: Türkiye Örneği”, Doktora Tezi, Hacettepe Ünivesitesi, Ankara.

Carmignani, F. (2003), "Political Instability, Uncertainty and Economics", Journal of Economic Surveys, Vol. 17(1), 1-54.

Demirgil, H. (2011), "Politik İstikrarsılık, Belirsizlik ve Makroekonomi: Türkiye Örneği: 19702006”, Marmara Üniversitesi IIIBF Dergisi, Cilt XXXI, Sayı: II, 123-144.

Drazen, A. (2002), Political Economy in Macroeconomics, Princeton: Princeton University Press.

Dutt, P. \& D. Mitra (2008), “Inequality and the Instability of Polity and Policy”, The Economic Journal, 118, 1285-1314.

Feridun, M. (2011), "Impact of Terrorism on Tourism in Turkey: Empirical Evidence from Turkey", Applied Economics, 43, 3349-3354.

Fosu, A.K. (2001), "Political Instability and Economic Growth in Developing Economies: Some Spesification Empirics", Economics Letters, 70, 289-294. 
İsmihan M. (2003), “The Role of Politics and Instabilty on Public Spending Dynamics and Macroeconomic Performance: Theory and Evidence From Turkey", Doktora Tezi, ODTÜ, Ankara.

Johnson, D.E. (1998), Applied Multivariate Methods for Data Analysts, Duxbury Press.

Jolliffe, I.T. (2002), Principal Component Analysis, Springer.

Jong-a-Pin, R. (2009), "On the Measurement of Political Instability and its Impact on Economic Growth", European Journal of Political Economy, 25, 15-29.

Keleş, R. \& A. Ünsal (1982), Kent ve Siyasal Şiddet, Ankara; AÜ SBF Basın ve Yayın Yüksek Okulu Yayınevi.

Lipset, S.M. (1959), "Some Social Requisities of Democracy: Economic Development and Political Legitimacy”, The American Political Science Review, Vol. 53(1), 69-105.

Lipset, S.M. (1964), Siyasî İnsan, Ankara: Türk Siyasî İlimler Derneği Yayını.

Mauro, P. (1995), “Corruption and Growth”, Quarterly Journal of Economics, Vol. 110(3), 681-712.

Milliyet (01.01.1955-31.12.2009 \& 01.01.1955-30.06.2004), <http:/gazetearsivi.milliyet.com.tr/>.

OECD (2008), Handbook on Constructing Composite Indicators: Methodology and User Guide, Paris: OECD Publications.

Öcal, N. \& J. Öcal (2010), "Regional Effects of Terrorism on Economic Growth in Turkey: A Geographically Weighted Regression Approach”, Journal of Peace Research, 47(4), pp.477-489.

Perotti, R. (1996), “Growth, Democracy, and Income: What the Data Say”, Journal of Economic Growth, 1, 149-187.

Raykov, T. \& G.A. Marcoulides (2008), An Introduction to Applied Multivariate Analysis, New York, Routledge.

Rencher, A.C. (2002), Methods of Multivariate Analysis (2. Ed.), Wiley-Interscience.

Sanders, D. (1981), Patterns of Political Instability, The Macmillan Press Ltd.

Şanlısoy, S. \& R. Kök (2010), "Politik İstikrarsızlık-Ekonomik Büyüme İlişkisi: Türkiye Örneği (1987-2006)”, Dokuz Eylül Üniversitesi İ̈BF Dergisi, Cilt: 25(1), 101-125.

Telatar, F. (2003a), “Türkiye'de Enflasyon, Enflasyon Belirsizliği ve Siyasî Belirsizlik Arasındaki Nedensellik İlişkileri”, İktisat İşletme ve Finans, 203, 42-51.

Telatar, F. (2003b), “Türkiye'de Politika Değişkenliği ile Ekonomik Büyüme Arasındaki Nedensellik İlişkileri”, İktisat İşletme ve Finans, 211, 71-91.

Telatar, F. (2003c), "Political Business Cycles in the Parliamentary Systems Evidence from Turkey", Emerging Markets Finance and Trade, Vol. 39(4), 24-39.

Telatar, E. \& F. Telatar (2004), "Standart IMF İstikrar Politikaları: Politik İstikrarsızlığa Yol Açan Bir Kanal”, İktisat Işletme ve Finans, Şubat, 53-65.

Telatar, E. \& F. Telatar \& T. Cavusoglu \& U. Tosun (2009), "Political Instability, Political Freedom and Inflation", Applied Economics, May, 1-9. 


\section{EK: 1}

\section{Türkiye'de Politik İstikrarsızlığın Makro Değişkenler Üzerindeki Etkisine İlişsin Çalıșmalar}

\begin{tabular}{|c|c|}
\hline Çalışma ve Dönemi & Kullanılan Politik Gösterge \\
\hline $\begin{array}{l}\text { Telatar }(2003 a), 1987.1- \\
\text { 2001.12, aylik veriler. }\end{array}$ & $\begin{array}{l}\text { Döviz kurundaki (TL/\$) değişim oranı (Siyasi belirsizliğin ölçümünde temsili } \\
\text { bir değişken olarak seçilmiştir). }\end{array}$ \\
\hline $\begin{array}{l}\text { Telatar (2003b), 1986-2001, } \\
\text { aylık veriler. }\end{array}$ & $\begin{array}{l}\text { Politika değişkenliği (Politika değişkenliğini yansıtmak üzere faiz oranı farkı } \\
\text { ve döviz kuru artış oranı kullanılmıştır). }\end{array}$ \\
\hline Telatar (2003c), 1986-1997. & Seçimler. \\
\hline $\begin{array}{l}\text { İsmihan (2003), 1963-1999, } \\
\text { y1llık veriler. }\end{array}$ & Makroekonomik İstikrarsızlık Endeksi ${ }^{13}$ \\
\hline $\begin{array}{l}\text { Telatar ve Telatar (2004), 1951- } \\
2001 \text { y1llık veriler. }\end{array}$ & Probit modeli ile tahmin edilen "askeri müdahale olma olasılığı." \\
\hline $\begin{array}{l}\text { Araz-Takay, Arın ve Omay } \\
(2009), 1987.1-2004.4 \text {, çeyrek } \\
\text { dönem verileri. }\end{array}$ & Terör endeksi ${ }^{14}$. \\
\hline $\begin{array}{l}\text { Öcal ve Yıldırım (2010); 1987- } \\
2001 .\end{array}$ & $\begin{array}{l}\text { Ortalama terörizm endeksi (terör olaylarının, yaralanma ve ölümlerin ortalama } \\
\text { sayısı). Bu endekse ilişkin veriler MIPT (Memorial Institute for the Prevention } \\
\text { of the Terrorism)'den alınmıştır. }\end{array}$ \\
\hline $\begin{array}{l}\text { Şanlısoy ve Kök (2010); } 1987- \\
\text { 2004, çeyrek dönem verileri. }\end{array}$ & Politik Risk Endeksi ${ }^{15}$ (ICRG'den alınmıştır). \\
\hline $\begin{array}{l}\text { Arslan (2011); 1987-2007, } \\
\text { çeyrek(?) dönem verileri. }\end{array}$ & $\begin{array}{l}\text { ICRG'den (International Country Risk Guide) alınan politik istikrarsılık } \\
\text { göstergesi. }\end{array}$ \\
\hline $\begin{array}{l}\text { Feridun (2011); 1986-2006, } \\
\text { y1llık veriler. }\end{array}$ & Terör olayları sonucunda ölen ve yaralanan kişi sayısı. \\
\hline $\begin{array}{l}\text { Demirgil (2011), 1970-2006, } \\
\text { y1llık veriler. }\end{array}$ & $\begin{array}{l}\text { Yerel ve genel seçimler, referandum, askeri müdahaleler, koalisyon } \\
\text { hükümetleri ve grev değişkenlerinden TBY kullanılarak elde edilen iki } \\
\text { endeks. }\end{array}$ \\
\hline
\end{tabular}

13 Bu endeks şu dört göstergeden oluşturulmaktadır: Enflasyon oranı (GSMH deflatörü), Kamu (konsolide bütçe) açı̆̆ı/GSMH oranı, (orta ve uzun vadeli) dış borç stoku/GSMH oranı ve \$/TL kurundaki değişiklikler. Endeks, değişkenlerin ölçü birimlerindeki farklılı̆̆ yönteme uygun olarak iki aşamalı bir prosedüre göre hesaplanmakta ve böyle elde edilen seri 0-1 aralı̆̆ında değerler almaktadır.

14 Terör endeksi Hürriyet Gazetesinden elde edilen veriler kullanılarak Log $(1+o ̈ l u ̈ ~ s a y ı s \imath+y a r a l ı ~ s a y \imath s \imath+$ terörist saldırı sayısı) formülüyle hesaplanmaktadır.

15 Endeksin şu 12 bileşenden oluştuğu belirtilmektedir: Hükümet istikrarl, sosyo-ekonomik koşullar, yatırım profili, içsel çatışmalar, dışsal çatışmalar, yolsuzluk, politik alanda askerin etkisi, politik alanda dinin etkisi, yasal düzenlemeler, etnik gerilimler, demokratik şeffaflı ve bürokrasi. 
EK: 2.1

Gosteri Değişkeni

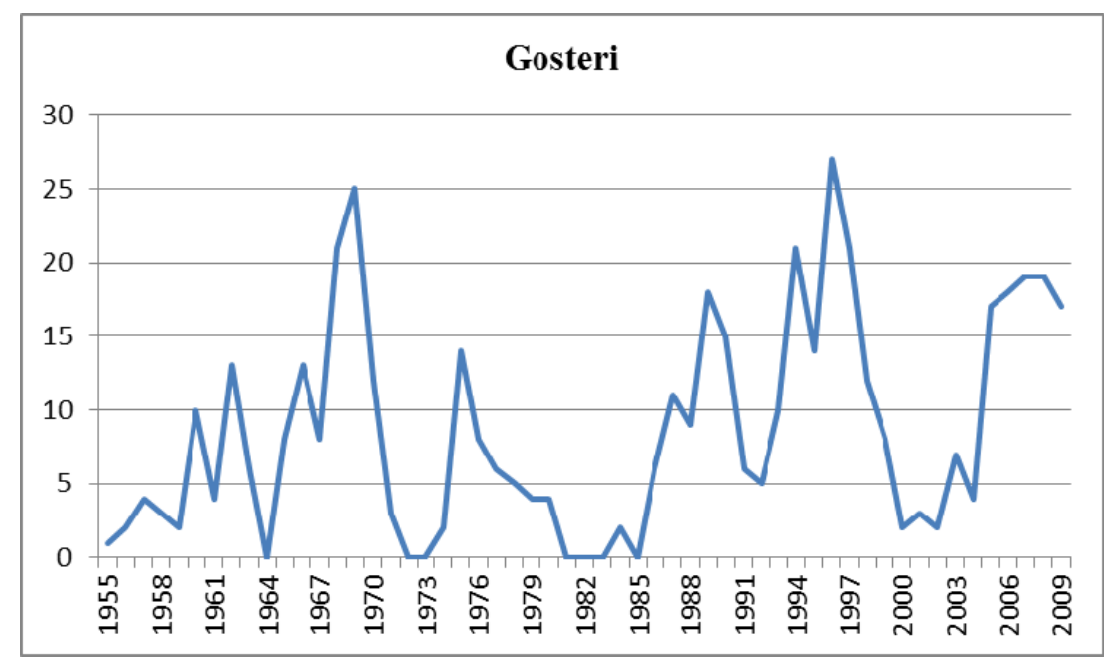

EK: 2.2

PKK Değişkeni

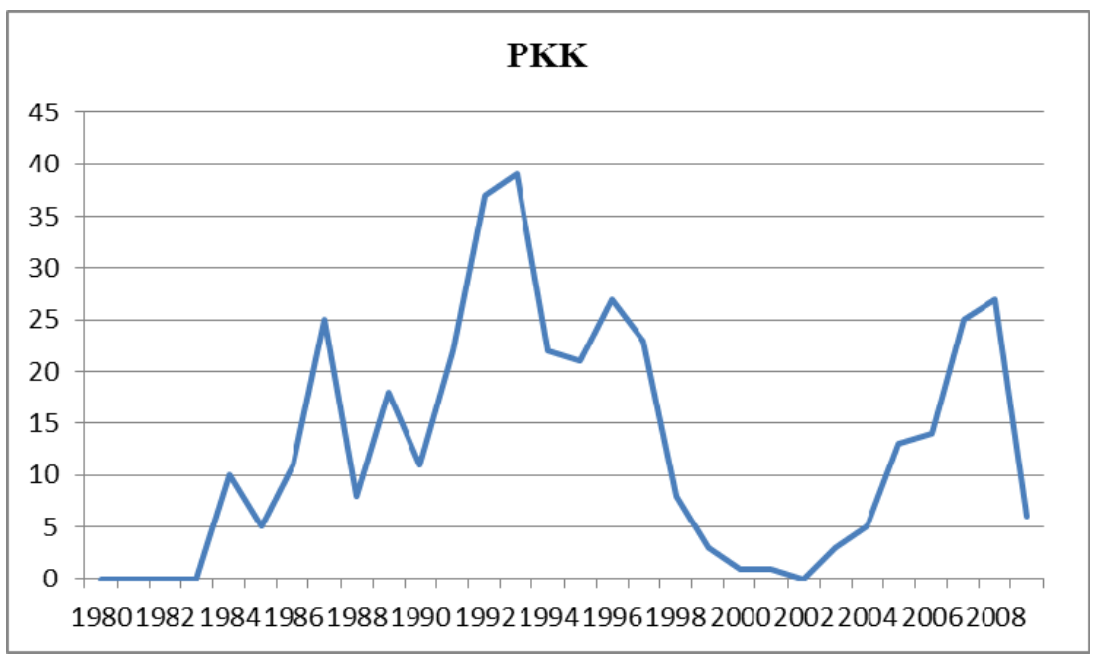




\section{EK: 2.3}

\section{Suikast Değişkeni}

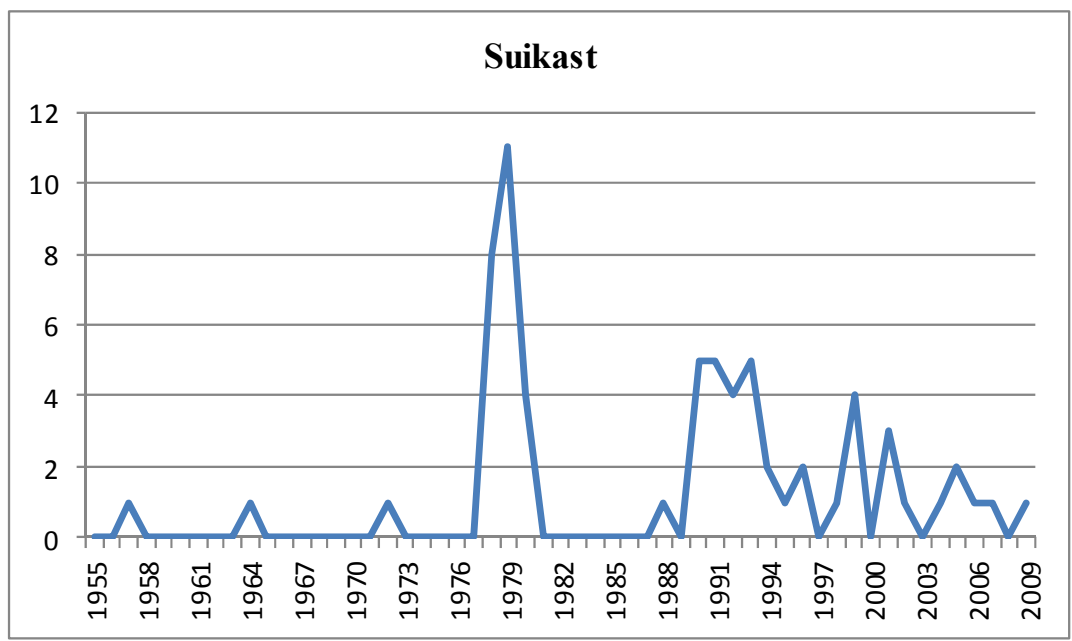

EK: 3.1

Politik İstikrarsızlık Endeksi TB2

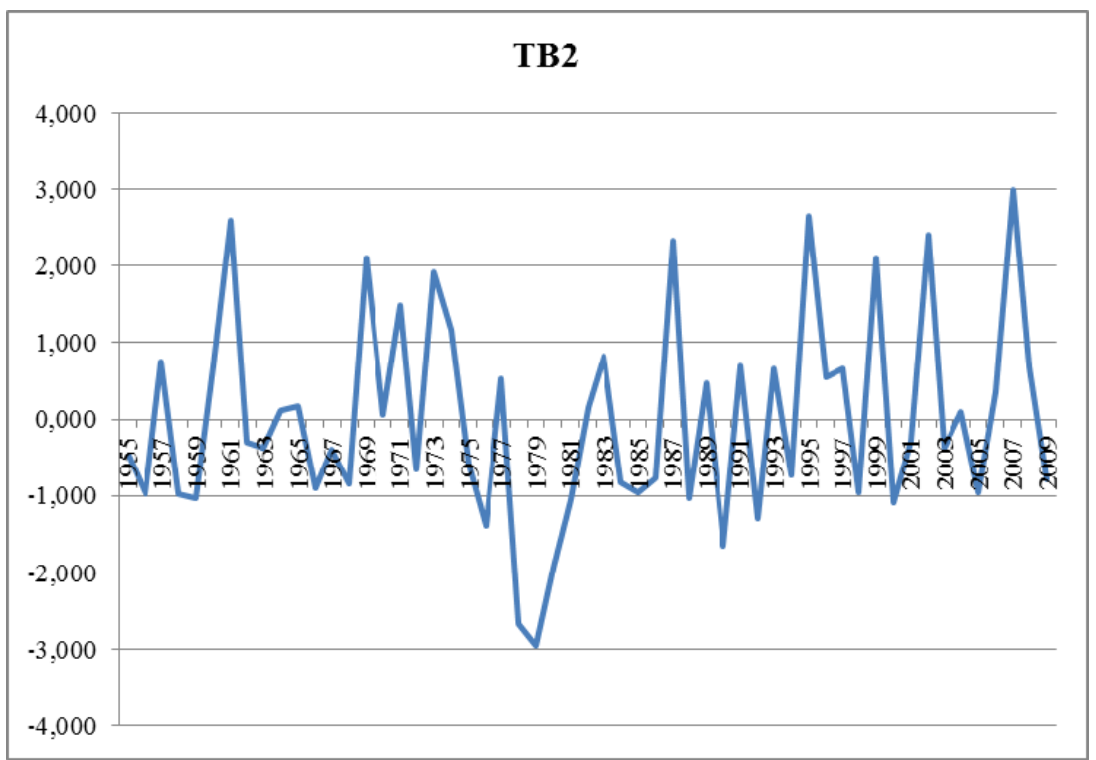


EK: 3.2

Politik İstikrarsızlık Endeksi TB3

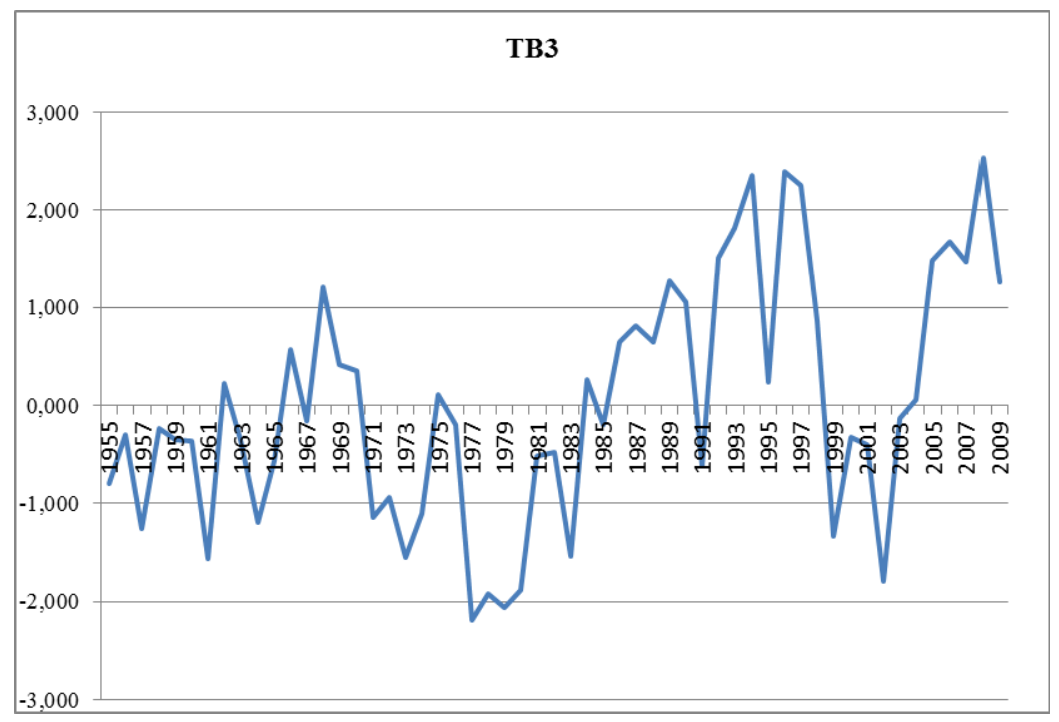

EK: 3.3

Politik İstikrarsızlık Endeksi TB4

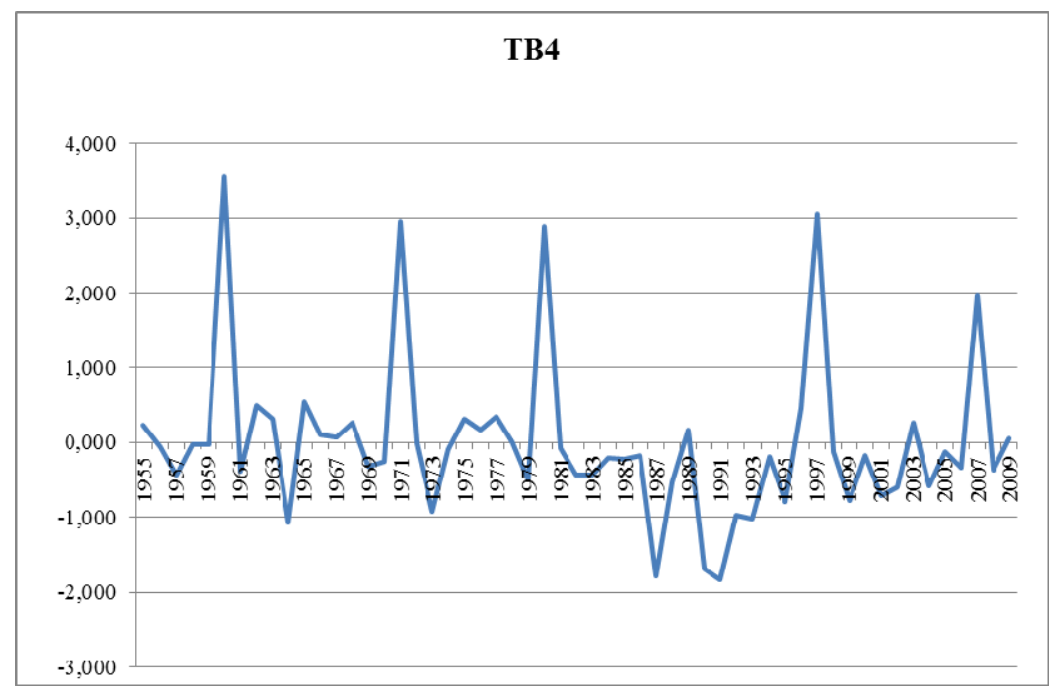

